\title{
The Epidemiology of Endometrial and Ovarian Cancer
}

\section{Citation}

Cramer, Daniel W. 2012. "The Epidemiology of Endometrial and Ovarian Cancer." Hematology/ Oncology Clinics of North America 26 (1) (February): 1-12. doi:10.1016/j.hoc.2011.10.009.

\section{Published Version}

doi:10.1016/j.hoc.2011.10.009

\section{Permanent link}

http://nrs.harvard.edu/urn-3:HUL.InstRepos:27332628

\section{Terms of Use}

This article was downloaded from Harvard University's DASH repository, and is made available under the terms and conditions applicable to Other Posted Material, as set forth at http:// nrs.harvard.edu/urn-3:HUL.InstRepos:dash.current.terms-of-use\#LAA

\section{Share Your Story}

The Harvard community has made this article openly available.

Please share how this access benefits you. Submit a story.

\section{Accessibility}




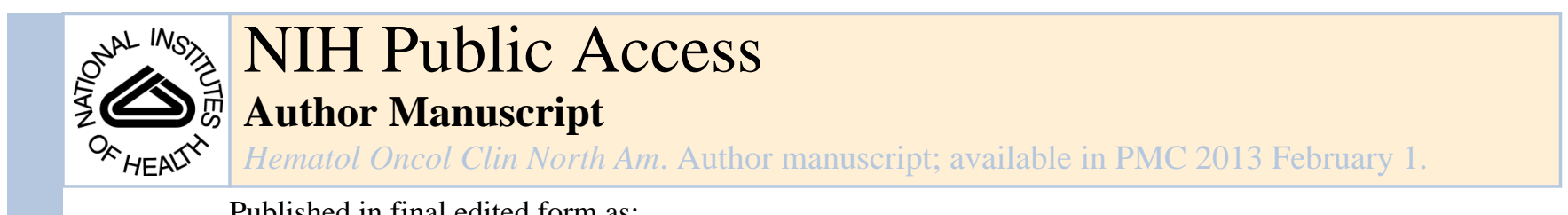

Published in final edited form as:

Hematol Oncol Clin North Am. 2012 February ; 26(1): 1-12. doi:10.1016/j.hoc.2011.10.009.

\title{
The Epidemiology of Endometrial and Ovarian Cancer
}

\author{
Daniel W. Cramer, M.D., Sc.D. \\ Brigham and Women's Hospital, Department of Obstetrics and Gynecology
}

\section{Introduction}

The epidemiology of ovarian cancer and endometrial cancer is closely entwined. Age specific incidence curves and the international rates for both sites parallel each other, and histologic subtypes of cancer arising from the endometrium mirror types found in the ovary. Most of the personal factors that increase or decrease risk for one of these cancers act in the same direction for the other. For these reasons, we will consider the epidemiology of ovarian and endometrial cancer together in this chapter with the goal of providing a more unified perspective. We will not address the epidemiology of cervical cancer in this chapter. This is not for lack of importance. Worldwide cervical cancer is a greater source of morbidity and mortality than endometrial and ovarian cancer combined (Table 1). However, there are many fewer epidemiologic uncertainties related to cervical cancer; and means of prevention and early detection are in hand, if not yet fully implemented where they are most needed.

\section{Tumor heterogeneity as it may affect epidemiologic associations}

Before discussing the epidemiology of endometrial and ovarian cancer, it must be pointed out that neither of these cancers is homogeneous from a histopathologic standpoint. Cancer registries often include endometrial cancer under the broader category "cancers of the uterine corpus," which includes sarcomas that arise from the endometrial stroma or from the smooth muscle of the uterus. Adenocarcinomas comprise the vast majority of cancers of the "uterine corpus" and most epidemiologic studies are restricted to these. In turn, endometrial adenocarcinomas may be further subdivided with endometrioid (or Type I) cancers accounting for majority, about $85 \%$, and the remainder designated Type II and including adenosquamous, serous papillary, clear cell, and undifferentiated types similar to those found in the ovary $[1,2]$.

There is an even greater degree of heterogeneity for ovarian cancer. Ovarian malignancies may arise from germ cell, stromal, or epithelial compartments. Counting benign neoplasms, about $25 \%$ of all ovarian tumors are of germ cell origin. Most common is the mature teratoma (dermoid) which accounts for nearly $1 / 3$ of all benign ovarian neoplasms, but only $2-3 \%$ of germ cell tumors are malignant [3]. Ovarian stromal tumors account for $6 \%$ of all benign and malignant ovarian tumors with the most common being the granulosa cell tumor which accounts for approximately $10 \%$ of malignant ovarian cancers. The most common types of malignant ovarian cancers are epithelial and parallel the same types arising in the endometrium. Four major histologic subtypes of epithelial ovarian cancer have been

() 2011 Elsevier Inc. All rights reserved.

Corresponding author: Brigham and Women's Hospital, Obstetrics and Gynecology Epidemiology Center, 221 Longwood Avenue RFB 365, Boston MA 02115, Phone: 617732 4895, Fax: 617732 4899, DCRAMER@PARTNERS.ORG.

Publisher's Disclaimer: This is a PDF file of an unedited manuscript that has been accepted for publication. As a service to our customers we are providing this early version of the manuscript. The manuscript will undergo copyediting, typesetting, and review of the resulting proof before it is published in its final citable form. Please note that during the production process errors may be discovered which could affect the content, and all legal disclaimers that apply to the journal pertain. 
described, each resembling different types of epithelia found in the female reproductive tract [4]. Features associated with fallopian tube, endocervical or endometrial epithelia are observed in serous, mucinous and endometrioid forms of ovarian cancer, respectively. Clear cell tumors are the fourth major histological subtype and are identified by clear, peg-like cells that resemble the lining of the endometrial glands during pregnancy. The majority of malignant ovarian tumors fall into the invasive serous category followed by endometrioid, clear cell, and mucinous types.

A distinction made for ovarian cancer that does not have an exact parallel in endometrial cancer is the designation of borderline or low malignant potential (LMP) ovarian tumor types that may spread beyond the ovary yet generally have an indolent course and account for about 17-18\% of ovarian cancers. The Surveillance, Epidemiology, and End Result (SEER) agency at the National Cancer Institute decided to no longer count LMP ovarian tumors as cancers after Jan 1, 2004. As a consequence, about a 20\% "decrease" in the incidence of ovarian cancer and a 5\% decrease in mortality occurred between 2004 and 2006.

In conclusion then, epidemiologic patterns observed for endometrial cancer are most likely to pertain to the Type I cancers while that for ovarian cancer to invasive serous. However, because of the greater heterogeneity of ovarian cancer, the mix of cases from study to study may influence epidemiologic associations reported for ovarian cancer especially if LMP tumors are included.

\section{Age and Geographic Distribution}

In the U.S., endometrial cancer is the most common gynecologic cancer accounting for 40,100 new cases and 7,470 deaths [5]. Ovarian cancer accounts for fewer cases $(21,650)$ but more deaths $(15,520)$ [5]. Ovarian cancer is the leading cause of death from a gynecologic cancer and fifth leading cause of cancer deaths overall in the U.S. Endometrial and ovarian cancer share similar patterns of distribution by age and geography. Both cancers rise sharply in occurrence during the perimenopausal years and peak well after the menopause (Fig 1). Endometrial cancer rates drop after age 70, but ovarian cancer rates continue to rise into a woman's eighties. It should be appreciated that the age specific rates for ovarian cancer calculated by SEER are based on the entire US population of females including those who have had hysterectomy or hysterectomy and oophorectomy [6]. Except when the operation was done for endometrial or ovarian cancer, women who have had such operations are virtually at no future risk for these cancers. Because of this, it is estimated that rates overall are about 33\% higher for endometrial cancer and about $15 \%$ higher for ovarian cancer, although the exact percentages differ somewhat by age [7]. The corresponding dashed lines in Figure 1 illustrate the predicted higher incidence rates for women who still have their uterus or ovaries. Using these corrected incidence rates, the lifetime risk for endometrial cancer is about $5.7 \%$ if women with hysterectomy for benign conditions are excluded and $2.5 \%$ for ovarian cancer if women with hysterectomy and oophorectomy are excluded.

Worldwide, higher rates of endometrial and ovarian cancer are observed in industrialized and Northern European populations and lower rates in third world countries [8] (Table 1). There is a positive correlation between endometrial cancer occurrence and ovarian cancer occurrence that is significant (Pearson correlation $=0.76, \mathrm{p}<0.001$ ). For comparison, the rates of cervical cancer are also shown and are inversely correlated with both endometrial cancer $($ Pearson correlation $=-0.64, \mathrm{p}<0.001)$ and ovarian cancer $($ Pearson correlation $=$ $-0.57, \mathrm{p}=0.003)$. 


\section{Risk Factors}

In this section we will consider personal risk factors for endometrial and ovarian cancers organized under the following headings: menstrual and reproductive events, medical history, and habits and environment (Table 2). Genetic risk for these cancers is treated in a separate chapter.

\section{Menstrual and reproductive events}

Personal risk factors for endometrial and ovarian cancer often operate in the same direction and many of these relate to menstrual and reproductive events. Factors that decrease risk for both endometrial and ovarian cancer include a late age at menarche $[9,10]$, early age at first birth [9-12] as well as last pregnancy at a later age [12-14], a greater number of children [9-14], and longer period of breastfeeding children [15-19]. With the exception of estrogen dominant sequential oral contraceptives, which case reports linked to endometrial cancer [20], longer use of combination oral contraceptives reduces the risk for both endometrial and ovarian cancer [21-24]. Short or irregular cycles $[9,10]$ and a late age at menopause are associated with increased risk for both endometrial cancer and ovarian cancers [13, 25]. These above events can be fit into a composite variable that estimates years of ovulation or, when average cycle length is included, number of ovulatory cycles. Increasing ovulatory cycles clearly correlates with increased risk for ovarian cancer [26, 27]. Though less well studied, ovulatory cycles also appears to correlate directly with endometrial cancer risk [28].

Despite the appeal of an ovulatory cycles model for consolidating many of the reproductive factors, it is also true that other contraceptive methods not associated with cessation of ovulation may also affect endometrial and ovarian cancer. IUD use, even hormonally inert types, decreases the risk for endometrial cancer $[29,30]$ and studies suggests IUD use (at least short term) may also decrease the risk for ovarian cancer [31, 32]. Similarly, tubal ligation is a strong protective risk factor for ovarian cancer that may also decrease the risk for endometrial cancer [33-36]. Finally, another risk factor for endometrial and ovarian cancer is menopausal hormone use, with higher risk largely confined to users of estrogen only forms unopposed by a progestin [37-42].

\section{Medical history}

High body mass index (BMI) is a well-established risk factor for Type I endometrial cancer and has been linked to elevated levels of estrogen, particularly in post-menopausal women where adipose tissue is the main site of estrogen production from androgen precursors [43-45]. High BMI also appears to be associated with increased ovarian cancer risk possibly through similar hormonal mechanisms, although the risk is not as strong as that for endometrial cancer [46-48]. Polycystic ovarian syndrome, a condition characterized by ovarian hyperandrogenism, chronic anovulation and progesterone deficiency, has also been associated with increased risk for both ovarian and endometrial cancer [49-51]. A history of bone fracture may decrease risk for endometrial and possibly ovarian cancer [32, 52, 53] and may reflect long-term hypoestrogenic status. For reasons not entirely clear Systemic Lupus Erythematosus (SLE) may decrease risk for endometrial and ovarian cancer [54].

\section{Habits and environmental factors}

Current smoking is associated with a reduced risk for endometrial cancer, particularly in postmenopausal women, possibly due to the anti-estrogenic effects of smoking such as reduced body weight, lower age at menopause and differences in estrogen metabolism [55]. Current smoking has also been associated with decreased risk of clear cell ovarian tumors, however no association was observed with serous and endometrioid tumors; and smoking doubled the risk of mucinous ovarian cancers [56]. Talc use is another factor found to 
consistently increase the risk for ovarian cancer [57] and recently reported to increase the risk for endometrial cancer as well [58] — raising intriguing questions related to the pathogenic mechanism underlying these associations. Increased exercise and physical activity decreases the risk for endometrial [59-61] and possibly ovarian cancer [62].

In summary, this brief review of epidemiologic risk factors for endometrial and ovarian cancers reveals a surprising number of similarities which suggests that there are also shared mechanisms in their pathogenesis.

\section{Mechanisms}

An ultimate goal of epidemiology is to clarify the biologic basis for observations made about a disease leading to a better understanding of its pathogenesis and strategies for its control. For endometrial cancer, it has been accepted for many years that its epidemiology is largely explained by conditions which lead to an excess of estrogen relative to progesterone. A "natural experiment" testing this explanation was the increase in endometrial cancer incidence which followed the increased use of unopposed estrogen to treat menopausal symptoms during the 1970's [63]. The strong link between obesity and endometrial cancer is likely explained by the fact that fat possesses aromatase capable of converting androstenedione into estrone, a biologically active estrogen [43]. The fact that endometrial cancer increases dramatically during the perimenopause when anovulatory cycles become more common provides further physiologic support. The protective effect of smoking on endometrial cancer risk may relate to possible anti-estrogen effects of smoking. However, it is more difficult to explain how estrogen excess fits with the association between endometrial cancer and ovulatory cycles and even less clear how IUD use, tubal ligation, or talc use fits with estrogen excess.

The most popular explanation for ovarian cancer risk factors is the "incessant ovulation" theory [64]; and this may be of interest to the connection between ovulatory cycles and endometrial cancer. For ovarian cancer, it has been proposed that the monthly disruption and repair of the surface epithelium of the ovary may lead to genetic damage due to the accumulation of mutations of the tumor suppressor, p53, in the ovarian and possible fallopian tube epithelium [65, 66]; but this mechanism would not explain the association with endometrial cancer. One possibility is that "incessant ovulation" largely equates with "incessant menstruation" involving repeated disruption and re-growth of the uterine lining. A greater number of cycles of endometrial regeneration may increase the likelihood of random genetic mutations because DNA replication errors occur during cell division, and thus are more likely to occur in tissues undergoing many cell divisions. Estimates of the rate of sporadic mutagenesis in human cells, on the order of $10^{-7}$ mutations per gene per cell division [67] suggest that the number of cells with "first hits" on a multistep carcinogenesis pathway [68] may number in the hundreds for every gram $\left(10^{9}\right.$ cells/gram $)$ of proliferative tissue. It is no surprise, then, to find that sporadic mutations of another tumor suppressor gene, PTEN, are observed in almost half (43\%) of histologically normal endometria of naturally cycling premenopausal women [69]. Thus accumulation of mutations in p53 or PTEN associated with reproductive tissue turnover could be the common explanation that links ovulatory cycles with both endometrial and ovarian cancer risk.

Another popular theory offered to explain ovarian cancer risk factors is inflammation associated with ovulation, talc use, or endometriosis [70]. This theory could explain why tubal ligation would be protective by blocking talc or menstrual debris from reaching the ovaries. However this theory would not explain why tubal ligation may also protect against endometrial cancer or why IUD use protects against endometrial and possibly ovarian 
cancer as well. No existing theory readily explains an inverse association between mumps parotitis and ovarian cancer reported in early studies [71, 72].

Recently, we proposed a new paradigm [32] for ovarian cancer that may also explain aspects of endometrial cancer risk as well. Risk factors for ovarian cancer may be determined by factors affecting the immune system-acute events in younger life which primed the immune system to recognize and eliminate ovarian cancer precursors and/or chronic events that led to persistent antigen challenge and immune tolerance of an emerging cancer [32]. The acute events include mumps, mastitis, tubal ligation, and others that affect tissues which express surface glycoproteins known as mucins (MUC), especially MUC1, including salivary glands, breast ducts, fallopian tubes, and others. Normally, MUC1 is expressed in low levels in a highly-glycosylated form, whereas, in cancer, MUC1 is expressed at high levels in a less-glycosylated form where backbone peptides are exposed to the immune system and evoke anti-MUC1 antibodies described in a variety of cancers [73] as well as certain inflammatory conditions like ulcerative colitis [74]. The "inflammatory" form of MUC1 is similar to the tumor-like form of MUC1 and hence might prime the immune system to recognize nascent cancer cells or precursor lesions which express this form of MUC1 [73]. The number and diversity of these acute events, their age at occurrence, and whether their benefits are negated by chronic inflammatory events determine whether effective, long-term immune surveillance is created. The chronic events like incessant ovulation, talc use, and endometriosis, also affect tissues that express MUC1 and may also lead to expression of an "inflammatory" form of mucins. However, because the events are chronic, we hypothesize they lead to immune-tolerance of an emerging cancer.

Supporting our theory are findings that events like tubal ligation and mastitis, which raised anti-MUC1 antibody levels in controls from the New England Case Control study, are associated with lower risk for ovarian cancer; and, conversely, factors that decreased antiMUC1 antibody levels (e.g. talc use and estimated ovulatory cycles) increased the risk for ovarian cancer $[32,75]$. Prospective data from the Nurses Health Studies (NHS) confirmed the importance of tubal ligation raising antibodies and ovulatory cycles lowering them [76]. Importantly, the NHS study found that the presence of anti-MUC1 antibodies in bloods drawn at least 3 years prior to a clinical diagnosis of ovarian cancer predicted lower risk for ovarian cancer in women less than 64 years of age at blood draw. In women $>64$ at blood draw a protective association was not apparent for two reasons. First, anti-MUC1 antibody levels in controls declined after age 64 likely due to aging of the immune system (immunosenescence)—a well described phenomenon in vaccine literature [77]. Secondly it would appear that women with the lowest anti-MUC1 antibody levels may develop ovarian cancer soonest leaving older women destined to develop ovarian cancer with relatively higher (but ineffective) levels of antibodies. As a final piece of evidence, we found that individuals going through a mumps infection have significantly higher anti-MUC1 antibody levels than blood bank or community controls providing evidence that mumps may have exerted its protective effect though MUC1 immunity [78].

In summary, reproductive tissue turnover as well as mucin-related immunity both offer more comprehensive explanations for endometrial and ovarian cancer risk factors than the separate models currently proposed. As we recently argued in a paper addressing immune surveillance in cancer [79], an appeal of an immune-based model is that it is capable of explaining risk factors for many types of cancer based upon possible deleterious effects of aging, obesity, smoking, lack of childhood illness, and even talc use on the immune system. 


\section{Strategies for prevention}

Epidemiologists are primarily concerned with ways to prevent disease from occurring in the first place or detecting the disease at an earlier stage so that it can be more successfully treated. Because many of the risk factors for endometrial and ovarian cancer are similar, suggestions for preventing endometrial cancer may pertain to ovarian cancer as well. Maintenance of a healthy weight and a lifetime commitment to exercise would be beneficial for both ovarian and endometrial cancer. Breastfeeding after pregnancy and use of birth control pills are two equally important recommendations to reduce risk. Avoiding talc in pelvic hygiene is good advice to women to lower ovarian cancer risk that may also help lower endometrial cancer risk as well. Many women come to hysterectomy for benign conditions and they are obviously no longer at risk for endometrial cancer. Careful selection of women for incidental oophorectomy would prevent them from developing ovarian cancer as well. We have recently describe a risk scoring scheme to help physicians and patients decide who might be advised to have oophorectomy [80].

There are currently no recommendations regarding general population screening for either endometrial or ovarian cancer, although screening may be warranted in groups at high risk for ovarian or endometrial cancer. Should more sensitive and specific screening tests become available, the sharply rising incidence of these cancers during the 50 to 65 age range suggests this would be a good age group to target screening efforts.

\section{Conclusion}

This review has highlighted similarities in the epidemiology of endometrial and ovarian cancer that includes highly correlated incidence rates and similar risk factor profiles. Factors that decrease risk for both cancers include a late menarche, early age at first birth, giving birth and breastfeeding, and use of oral contraceptives. Short or irregular cycles and late menopause is associated with increased risk for both. Other risk factors that appear to operate in a similar direction include decreased risk associated with IUD use or a tubal ligation and increased risk associated with obesity, lack of exercise, and use of talc powders in genital hygiene. Estrogen excess is proposed as the underlying mechanism for most endometrial cancer while incessant ovulation has been suggested as the explanation for ovarian cancer. However, an increased number of estimated ovulatory cycles correlates directly with both endometrial and ovarian cancer risk suggesting that reproductive tissue turnover with an accumulation of PTEN or p53 mutation represents a possible common mechanism. An immune-based explanation involving mucin proteins represents another common mechanism that could explain additional risk factors. Maintenance of ideal weight, breastfeeding children, use of oral contraceptives, and avoidance of talc powders in genital hygiene are measures that could lower risk for both types of cancer. Careful selection of women for prophylactic oophorectomy for women who are coming to hysterectomy for benign disease is an additional measure to consider for ovarian cancer.

\section{Acknowledgments}

This work was supported by NIH Grant U01CA086381 and P50 CA105009.

\section{References}

1. Bokhman JV. Two pathogenetic types of endometrial carcinoma. Gynecol Oncol. 1983; 15(1):10-7. [PubMed: 6822361]

2. Deligdisch L, Holinka CF. Endometrial carcinoma: two diseases? Cancer Detect Prev. 1987; 10(3-4):237-46. [PubMed: 3568022] 
3. Scully, R. Tumors of the ovary and maldeveloped gonads. Vol Second Series. Washington, DC: Armed Forces Institute of Pathology; 1979.

4. Russell, P. Surface epithelial-stromal tumors of the ovary. In: Kurman, RJ., editor. Blaustein's Pathology of the Female Genital Tract. 4. New York: Springer-Verlag; 1994. p. 705-82.

5. American Cancer Society. Cancer Facts and Figures 2008. 2008

6. Ries, L.; Melbert, D.; Krapcho, M., et al. SEER Cancer Statistics Review, 1975-2005. 2008. http://seer.cancer.gov/csr/1975_2005/

7. Merrill RM. Impact of hysterectomy and bilateral oophorectomy on race-specific rates of corpus, cervical, and ovarian cancers in the United States. Ann Epidemiol. 2006; 16(12):880-7. [PubMed: 17027290]

8. Ferley, J.; Shin, HR.; Bray, F., et al. GLOBOCAN 2008 v1.2, Cancer Incidence and Mortality Worldwide: IARC CancerBase No. 10 [Internet]. Lyon, France: International Agency for Research on Cancer; 2010. Available from: http://globocan.iarc.fr

9. Brinton LA, Berman ML, Mortel R, et al. Reproductive, menstrual, and medical risk factors for endometrial cancer: results from a case-control study. Am J Obstet Gynecol. 1992; 167(5):1317-25. [PubMed: 1442985]

10. Titus-Ernstoff L, Perez K, Cramer DW, et al. Menstrual and reproductive factors in relation to ovarian cancer risk. Br J Cancer. 2001; 84(5):714-21. [PubMed: 11237375]

11. Henderson BE, Casagrande JT, Pike MC, et al. The epidemiology of endometrial cancer in young women. Br J Cancer. 1983; 47(6):749-56.2011352 [PubMed: 6860544]

12. Whittemore AS, Harris R, Itnyre J. Characteristics relating to ovarian cancer risk: collaborative analysis of 12 US case-control studies II Invasive epithelial ovarian cancers in white women Collaborative Ovarian Cancer Group. Am J Epidemiol. 1992; 136(10):1184-203. [PubMed: 1476141]

13. Dossus L, Allen N, Kaaks R, et al. Reproductive risk factors and endometrial cancer: the European Prospective Investigation into Cancer and Nutrition. Int J Cancer. 2010; 127(2):442-51. [PubMed: 19924816]

14. Lambe M, Wuu J, Weiderpass E, et al. Childbearing at older age and endometrial cancer risk (Sweden). Cancer Causes Control. 1999; 10(1):43-9. [PubMed: 10334641]

15. Newcomb PA, Trentham-Dietz A. Breast feeding practices in relation to endometrial cancer risk, USA. Cancer Causes Control. 2000; 11(7):663-7. [PubMed: 10977111]

16. Okamura C, Tsubono $\mathrm{Y}$, Ito $\mathrm{K}$, et al. Lactation and risk of endometrial cancer in Japan: a casecontrol study. Tohoku J Exp Med. 2006; 208(2):109-15. [PubMed: 16434833]

17. Rosenblatt KA, Thomas DB. Prolonged lactation and endometrial cancer WHO Collaborative Study of Neoplasia and Steroid Contraceptives. Int J Epidemiol. 1995; 24(3):499-503. [PubMed: 7672888]

18. Salazar-Martinez E, Lazcano-Ponce EC, Gonzalez Lira-Lira G, et al. Reproductive factors of ovarian and endometrial cancer risk in a high fertility population in Mexico. Cancer Res. 1999; 59(15):3658-62. [PubMed: 10446978]

19. Siskind V, Green A, Bain C, et al. Breastfeeding, menopause, and epithelial ovarian cancer. Epidemiology. 1997; 8(2):188-91. [PubMed: 9229212]

20. Silverberg SG, Makowski EL. Endometrial carcinoma in young women taking oral contraceptive agents. Obstet Gynecol. 1975; 46(5):503-6. [PubMed: 1196551]

21. La Vecchia C. Oral contraceptives and ovarian cancer: an update 1998-2004. Eur J Cancer Prev. 2006; 15(2):117-24. [PubMed: 16523008]

22. Maxwell GL, Schildkraut JM, Calingaert B, et al. Progestin and estrogen potency of combination oral contraceptives and endometrial cancer risk. Gynecol Oncol. 2006; 103(2):535-40. [PubMed: 16740300]

23. Schlesselman JJ. Risk of endometrial cancer in relation to use of combined oral contraceptives A practitioner's guide to meta-analysis. Hum Reprod. 1997; 12(9):1851-63. [PubMed: 9363696]

24. Weiderpass E, Adami HO, Baron JA, et al. Use of oral contraceptives and endometrial cancer risk (Sweden). Cancer Causes Control. 1999; 10(4):277-84. [PubMed: 10482486] 
25. Chiaffarino F, Pelucchi C, Parazzini F, et al. Reproductive and hormonal factors and ovarian cancer. Ann Oncol. 2001; 12(3):337-41. [PubMed: 11332145]

26. Casagrande JT, Louie EW, Pike MC, et al. "Incessant ovulation” and ovarian cancer. Lancet. 1979; 2(8135):170-3. [PubMed: 89281]

27. Purdie DM, Bain CJ, Siskind V, et al. Ovulation and risk of epithelial ovarian cancer. Int J Cancer. 2003; 104(2):228-32. [PubMed: 12569579]

28. McPherson CP, Sellers TA, Potter JD, et al. Reproductive factors and risk of endometrial cancer The Iowa Women's Health Study. Am J Epidemiol. 1996; 143(12):1195-202. [PubMed: 8651218]

29. Beining RM, Dennis LK, Smith EM, et al. Meta-analysis of intrauterine device use and risk of endometrial cancer. Ann Epidemiol. 2008; 18(6):492-9. [PubMed: 18261926]

30. Hubacher D, Grimes DA. Noncontraceptive health benefits of intrauterine devices: a systematic review. Obstet Gynecol Surv. 2002; 57(2):120-8. [PubMed: 11832788]

31. Ness RB, Dodge RC, Edwards RP, et al. Contraception methods, beyond oral contraceptives and tubal ligation, and risk of ovarian cancer. Ann Epidemiol. 2011; 21(3):188-96.PMC3052991 [PubMed: 21109450]

32. Cramer DW, Titus-Ernstoff L, McKolanis JR, et al. Conditions associated with antibodies against the tumor-associated antigen MUC1 and their relationship to risk for ovarian cancer. Cancer Epidemiol Biomarkers Prev. 2005; 14(5):1125-31. [PubMed: 15894662]

33. Castellsague X, Thompson WD, Dubrow R. Tubal sterilization and the risk of endometrial cancer. Int J Cancer. 1996; 65(5):607-12. [PubMed: 8598311]

34. Green A, Purdie D, Bain C, et al. Tubal sterilisation, hysterectomy and decreased risk of ovarian cancer. Int J Cancer. 1997; 71:948-51. [PubMed: 9185694]

35. Lacey JV Jr, Brinton LA, Mortel R, et al. Tubal sterilization and risk of cancer of the endometrium. Gynecol Oncol. 2000; 79(3):482-4. [PubMed: 11104624]

36. Rosenblatt K, Thomas D. Association between tubal ligation and endometrial cancer. Int J Cancer. 1997; 71(1):129-30. [PubMed: 9096677]

37. Beral V, Bull D, Reeves G. Endometrial cancer and hormone-replacement therapy in the Million Women Study. Lancet. 2005; 365(9470):1543-51. [PubMed: 15866308]

38. Garg PP, Kerlikowske K, Subak L, et al. Hormone replacement therapy and the risk of epithelial ovarian carcinoma: a meta-analysis. Obstet Gynecol. 1998; 92(3):472-9. [PubMed: 9721791]

39. Grady D, Gebretsadik T, Kerlikowske K, et al. Hormone replacement therapy and endometrial cancer risk: a meta-analysis. Obstet Gynecol. 1995; 85(2):304-13. [PubMed: 7824251]

40. Pearce CL, Chung K, Pike MC, et al. Increased ovarian cancer risk associated with menopausal estrogen therapy is reduced by adding a progestin. Cancer. 2009; 115(3):531-9. [PubMed: 19127543]

41. Rodriguez C, Patel AV, Calle EE, et al. Estrogen replacement therapy and ovarian cancer mortality in a large prospective study of US women. Jama. 2001; 285(11):1460-5. [PubMed: 11255422]

42. Rossouw JE, Anderson GL, Prentice RL, et al. Risks and benefits of estrogen plus progestin in healthy postmenopausal women: principal results From the Women's Health Initiative randomized controlled trial. Jama. 2002; 288(3):321-33. [PubMed: 12117397]

43. Calle EE, Kaaks R. Overweight, obesity and cancer: epidemiological evidence and proposed mechanisms. Nat Rev Cancer. 2004; 4(8):579-91. [PubMed: 15286738]

44. Swanson CA, Potischman N, Wilbanks GD, et al. Relation of endometrial cancer risk to past and contemporary body size and body fat distribution. Cancer Epidemiol Biomarkers Prev. 1993; 2(4): 321-7. [PubMed: 8348055]

45. Weiderpass E, Persson I, Adami HO, et al. Body size in different periods of life, diabetes mellitus, hypertension, and risk of postmenopausal endometrial cancer (Sweden). Cancer Causes Control. 2000; 11(2):185-92. [PubMed: 10710204]

46. Leitzmann MF, Koebnick C, Danforth KN, et al. Body mass index and risk of ovarian cancer. Cancer. 2009; 115(4):812-22. [PubMed: 19127552]

47. Schouten LJ, Rivera C, Hunter DJ, et al. Height, body mass index, and ovarian cancer: a pooled analysis of 12 cohort studies. Cancer Epidemiol Biomarkers Prev. 2008; 17(4):902-12. [PubMed: 18381473] 
48. Kuper H, Cramer DW, Titus-Ernstoff L. Risk of ovarian cancer in the United States in relation to anthropometric measures: does the association depend on menopausal status? Cancer Causes Control. 2002; 13(5):455-63. [PubMed: 12146850]

49. Escobedo LG, Lee NC, Peterson HB, et al. Infertility-associated endometrial cancer risk may be limited to specific subgroups of infertile women. Obstet Gynecol. 1991; 77(1):124-8. [PubMed: 1984211]

50. Schildkraut JM, Schwingl PJ, Bastos E, et al. Epithelial ovarian cancer risk among women with polycystic ovary syndrome. Obstet Gynecol. 1996; 88(4 Pt 1):554-9. [PubMed: 8841217]

51. Wild S, Pierpoint T, Jacobs H, et al. Long-term consequences of polycystic ovary syndrome: results of a 31 year follow-up study. Hum Fertil (Camb). 2000; 3(2):101-5. [PubMed: 11844363]

52. Persson I, Adami HO, McLaughlin JK, et al. Reduced risk of breast and endometrial cancer among women with hip fractures (Sweden). Cancer Causes Control. 1994; 5(6):523-8. [PubMed: 7827239]

53. Newcomb PA, Trentham-Dietz A, Egan KM, et al. Fracture history and risk of breast and endometrial cancer. Am J Epidemiol. 2001; 153(11):1071-8. [PubMed: 11390325]

54. Bernatsky S, Ramsey-Goldman R, Foulkes WD, et al. Breast, ovarian, and endometrial malignancies in systemic lupus erythematosus: a meta-analysis. Br J Cancer. 2011; 104(9):147881.3101932 [PubMed: 21487409]

55. Terry PD, Rohan TE, Franceschi S, et al. Cigarette smoking and the risk of endometrial cancer. Lancet Oncol. 2002; 3(8):470-80. [PubMed: 12147433]

56. Jordan SJ, Whiteman DC, Purdie DM, et al. Does smoking increase risk of ovarian cancer? A systematic review. Gynecol Oncol. 2006; 103(3):1122-9. [PubMed: 17005245]

57. Cramer DW, Liberman RF, Titus-Ernstoff L, et al. Genital talc exposure and risk of ovarian cancer. Int J Cancer. 1999; 81(3):351-6. [PubMed: 10209948]

58. Karageorgi S, Gates MA, Hankinson SE, et al. Perineal use of talcum powder and endometrial cancer risk. Cancer Epidemiol Biomarkers Prev. 2010; 19(5):1269-75.2866017 [PubMed: 20406962]

59. John EM, Koo J, Horn-Ross PL. Lifetime physical activity and risk of endometrial cancer. Cancer Epidemiol Biomarkers Prev. 2010; 19(5):1276-83. [PubMed: 20406960]

60. Friedenreich CM, Cook LS, Magliocco AM, et al. Case-control study of lifetime total physical activity and endometrial cancer risk. Cancer Causes Control. 2010; 21(7):1105-16.2883088 [PubMed: 20336482]

61. Arem H, Irwin ML, Zhou Y, et al. Physical activity and endometrial cancer in a population-based case-control study. Cancer Causes Control. 2011; 22(2):219-26.3075067 [PubMed: 21110224]

62. Olsen CM, Bain CJ, Jordan SJ, et al. Recreational physical activity and epithelial ovarian cancer: a case-control study, systematic review, and meta-analysis. Cancer Epidemiol Biomarkers Prev. 2007; 16(11):2321-30. [PubMed: 18006921]

63. Weiss NS, Szekely DR, Austin DF. Increasing incidence of endometrial cancer in the United States. N Engl J Med. 1976; 294(23):1259-62. [PubMed: 1264151]

64. Fathalla MF. Incessant ovulation - a factor in ovarian neoplasia? Lancet. 1971; 2(7716):163. [PubMed: 4104488]

65. Schildkraut JM, Bastos E, Berchuck A. Relationship between lifetime ovulatory cycles and overexpression of mutant p53 in epithelial ovarian cancer. J Natl Cancer Inst. 1997; 89(13):932-8. [PubMed: 9214672]

66. Saleemuddin A, Folkins AK, Garrett L, et al. Risk factors for a serous cancer precursor ("p53 signature") in women with inherited BRCA mutations. Gynecol Oncol. 2008; 111(2):22632.2613977 [PubMed: 18718648]

67. Cairns J. Mutation and cancer: the antecedents to our studies of adaptive mutation. Genetics. 1998; 148(4):1433-40. [PubMed: 9560363]

68. Moolgavkar SH, Knudson AG Jr. Mutation and cancer: a model for human carcinogenesis. J Natl Cancer Inst. 1981; 66(6):1037-52. [PubMed: 6941039]

69. Mutter GL, Ince TA, Baak JP, et al. Molecular identification of latent precancers in histologically normal endometrium. Cancer Res. 2001; 61(11):4311-4. [PubMed: 11389050] 
70. Ness RB, Cottreau C. Possible role of ovarian epithelial inflammation in ovarian cancer. J Natl Cancer Inst. 1999; 91(17):1459-67. [PubMed: 10469746]

71. Newhouse ML, Pearson RM, Fullerton JM, et al. A case control study of carcinoma of the ovary. Br J Prev Soc Med. 1977; 31(3):148-53. [PubMed: 588853]

72. West RO. Epidemiologic study of malignancies of the ovaries. Cancer. 1966; 19(7):1001-7. [PubMed: 5939299]

73. Ho SB, Niehans GA, Lyftogt C, et al. Heterogeneity of mucin gene expression in normal and neoplastic tissues. Cancer Res. 1993; 53(3):641-51. [PubMed: 7678777]

74. Hinoda Y, Nakagawa N, Nakamura H, et al. Detection of a circulating antibody against a peptide epitope on a mucin core protein, MUC1, in ulcerative colitis. Immunol Lett. 1993; 35(2):163-8. [PubMed: 7685318]

75. Terry KL, Titus-Ernstoff L, McKolanis JR, et al. Incessant ovulation, mucin 1 immunity, and risk for ovarian cancer. Cancer Epidemiol Biomarkers Prev. 2007; 16(1):30-5. [PubMed: 17220329]

76. Pinheiro SP, Hankinson SE, Tworoger SS, et al. Anti-MUC1 antibodies and ovarian cancer risk: prospective data from the Nurses' Health Studies. Cancer Epidemiol Biomarkers Prev. 2010; 19(6):1595-601.2887719 [PubMed: 20501761]

77. Kumar R, Burns EA. Age-related decline in immunity: implications for vaccine responsiveness. Expert review of vaccines. 2008; 7(4):467-79. [PubMed: 18444893]

78. Cramer DW, Vitonis AF, Pinheiro SP, et al. Mumps and ovarian cancer: modern interpretation of an historic association. Cancer Causes Control. 2010; 21(8):1193-201.2951028 [PubMed: 20559706]

79. Cramer DW, Finn OJ. Epidemiologic perspective on immune-surveillance in cancer. Curr Opin Immunol. 2011; 23(2):265-71.3073666 [PubMed: 21277761]

80. Vitonis AF, Titus-Ernstoff L, Cramer DW. Assessing ovarian cancer risk when considering elective oophorectomy at the time of hysterectomy. Obstet Gynecol. 2011; 117(5):1042-50. PMC in process. [PubMed: 21471855] 


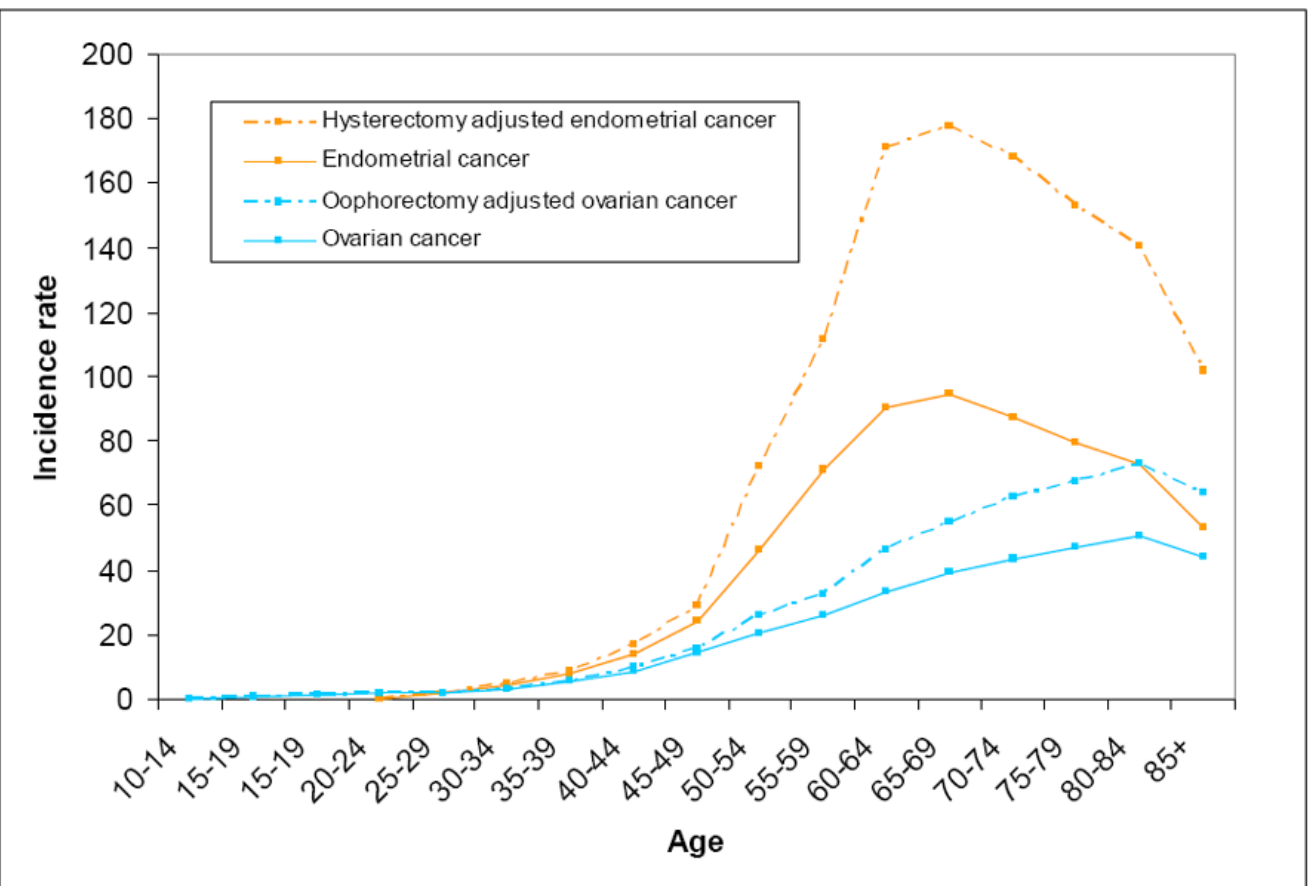

Figure 1.

Age-Specific Incidence Rates of Endometrial and Ovarian Cancers ${ }^{1}$.

${ }^{1}$ Age-Specific Cancer Incidence Rates are per 100,000 and are age-adjusted. Rates include all races and pertain to invasive cancers only. [6] 
